\title{
Pulmonary artery stump thrombosis developed during the late postoperative period
}

\author{
Tevfik Ilker Akcam, Seyda Ors Kaya, Ozgur Samancilar, Kenan Can Ceylan
}

Dr. Suat Seren Chest Diseases and Thoracic Surgery Training and Research Hospital, Izmir, Turkey

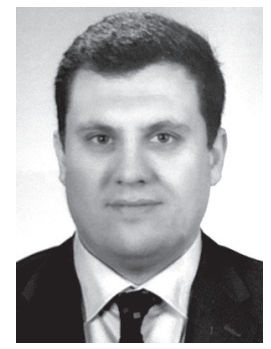

Kardiochirurgia i Torakochirurgia Polska 2016; 13 (3): 260-261

\begin{abstract}
A 73-year-old man underwent left pneumonectomy for squamous cell lung carcinoma 3 years ago. The postoperative and follow-up periods were uneventful. A thrombus was detected in the left pulmonary artery stump during the last chest computed tomography (CT) scan. Anticoagulant treatment was applied: intravenous heparin for 3 days followed by oral warfarin. The follow-up chest CT examination revealed regression in the size of the thrombus.
\end{abstract}

Key words: pulmonary artery stump, thrombosis, pneumonectomy.

\section{Case report}

A 73-year-old man underwent left pneumonectomy for squamous cell lung carcinoma 3 years ago. The pathological stage was Ila (T2aNOMO), and the vascular resection margins were free of tumor. No adjuvant treatment was applied. The postoperative and the follow-up periods were uneventful. However, a thrombus was detected in the left pulmonary artery stump during the last chest computed tomography (CT) scan (Fig. 1). Venous Doppler ultraso-

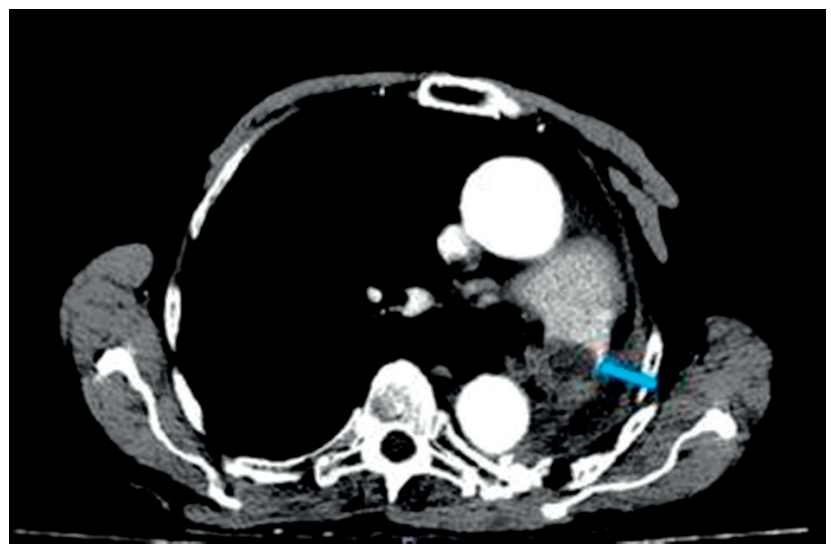

Fig. 1. Computed tomography image: secondary changes after left pneumonectomy - compensation. The arrow shows the thrombus in the stump of the left pulmonary artery

\section{Streszczenie}

U 73-letniego pacjenta 3 lata wcześniej wykonano pneumonektomię lewostronną z powodu płaskonabłonkowego raka płuca. W okresie pooperacyjnym i obserwacyjnym nie stwierdzono powikłań. W ostatnim badaniu tomografii komputerowej (TK) klatki piersiowej obecne były skrzepliny w kikucie lewej tętnicy płucnej. Zastosowano leczenie przeciwzakrzepowe: dożylną heparynę przez 3 dni, a następnie doustną warfarynę. W kolejnych badaniach TK klatki piersiowej odnotowano zmniejszenie rozmiaru skrzepliny.

Słowa kluczowe: kikut tętnicy płucnej, zakrzepica, pneumonektomia.

nography of both lower extremities detected no deep vein thrombosis. Anticoagulant treatment was applied: intravenous heparin for 3 days followed by oral warfarin. The follow-up chest $\mathrm{CT}$ revealed regression in the size of the thrombus (Fig. 2). Pulmonary artery stump thrombosis was reported as early as 1938 by Crafoord [1]. The frequency of artery stump thrombosis development following pneumonectomy has been reported as $12-20 \%$; however, the number of cases and studies on this subject is limited [2]. Par-

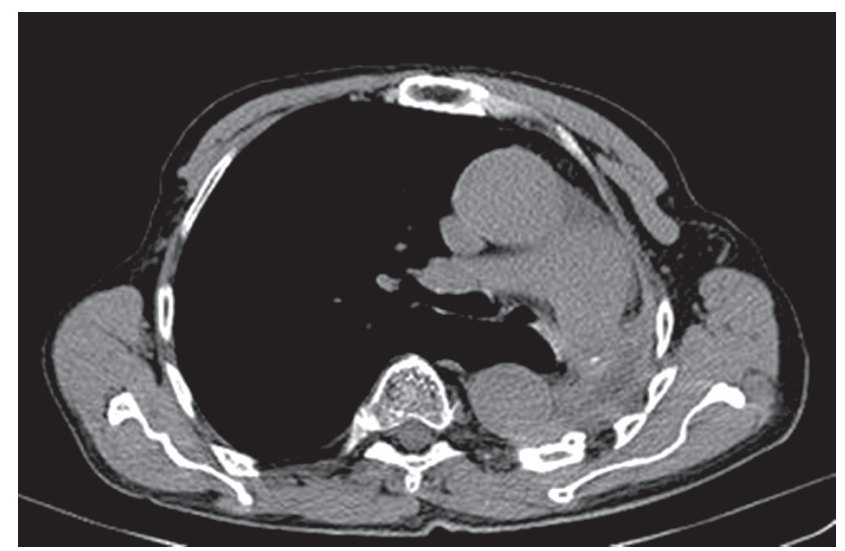

Fig. 2. Regression in the size of the thrombus observed on the follow-up chest computed tomography scan

Address for correspondence: Tevfik Ilker Akcam MD, Dr. Suat Seren Chest Diseases and Thoracic Surgery Training and Research Hospital, Yenisehir, Konak, 35510 Izmir, Turkey, phone: +90 5386062581, e-mail: tevfikilkerakcam@hotmail.com

Received: 25.03.2015, accepted: 25.03.2016. 
ticularly in the case of pneumonectomy, an embolus that develops in the opposite lung can be fatal, but the unfavorable consequences may be prevented with prompt diagnosis and treatment $[3,4]$. The described condition generally develops during the early postoperative period; in our case, however, it presented during the long-term follow-up. The initial treatment of choice is anticoagulant therapy. It has also been reported that successful treatment results were achieved in patients undergoing emergency thromboembolectomy [3]. There are also studies indicating that perioperative thromboembolic prophylaxis may be effective in preventing stump thrombosis [3]. As this condition can lead to life-threatening complications, detecting it is vitally important. The condition is mostly encountered during the early postoperative period; however, one should keep in mind that it may also develop during long-term follow-up. We hereby share the CT image in order to facilitate the di- agnosis of cases in which no postoperative complications are initially encountered, but in which stump thrombosis develops during long-term follow-up.

\section{Disclosure}

Authors report no conflict of interest.

\section{References}

1. Crafoord C. On the technique of pneumonectomy in man: critical survey of experimental and clinical development and report of authors material and techniques. Acta Chir Scand 1938; 81: 1-142.

2. Kotoulas C, Lachanis S. Embolism of the pulmonary artery stump after right pneumonectomy. Interact Cardiovasc Thorac Surg 2009; 8: 563-564.

3. Chen Q, Tang AT, Tsang GM. Acute pulmonary thromboembolism complicating pneumonectomy: successful operative management. Eur J Cardiothorac Surg 2001; 19: 223-225.

4. Sato W, Watabene H, Sato T, lino K, Sato K, Ito H. Contralateral pulmonary embolism caused by pulmonary artery stump thrombosis after pneumonectomy. Ann Thorac Surg 2014; 97: 1797-1798. 